\title{
Hubungan Tingkat Pengetahuan Tentang Hiv/Aids Dengan Motivasi Tes Hiv Pada Wanita Pekerja Seks (WPS) Di Lokalisasi Bukit Sungkai Km 12 Palangka Raya
}

\author{
Rizka Ovany1, Hermanto2, Widi Tramigo3 \\ 1Program Studi Kesehatan Masyarakat STIKES Eka Harap Palangka Raya \\ ${ }_{2}$ Program Studi Sarjana Keperawatan STIKES Eka Harap Palangka Raya \\ 3Program Studi Sarjana Keperawatan STIKES Eka Harap Palangka Raya \\ e-mail: hermantosuhin87@gmail.com
}

DOI: $10.33859 / \mathrm{dksm} . v 11 \mathrm{i1} .615$

\begin{abstract}
Abstrak
Latar Belakang :Human Immunodeficiency Virus (HIV) adalah jenis virus yang menyerang sistem kekebalan tubuh. Acquired Immunedeficiency Syndrome (AIDS) adalah suatu kumpulan gejala penyakit kerusakan sistem kekebalan tubuh. Voluntary Counselling Testing (VCT) adalah suatu program yang bertujuan untuk melakukan skrining HIV dengan beberapa persyaratan. Dengan pengetahuan WPS yang meningkat tentang HIV/AIDS, WPS dapat mengetahui, mempersiapkan, meyakini dan sebagainya sehingga menimbulkan motivasi niat untuk bertindak dan akhirnya terjadilah perwujudan niat yang berupa perilaku untuk melakukan tes HIV.Penelitian ini bertujuan untuk mengetahui "Apakah ada hubungan tingkat pengetahuan tentang HIV/AIDS dengan motivasi tes HIV pada wanita pekerja seks (WPS) di Lokalisasi Bukit Sungkai Km. 12 Palangka Raya".

Metode: Penelitian ini menggunakan penelitian korelasi dengan pendekatan cross- sectional yaitu jenis penelitian yang menekan waktu pengukuran atau observasi data variable independen dan dependen hanya satu kali pada satu saat (point time approach). Pengumpulan data menggunakan alat ukur kuisioner.

Hasil: Berdasarkan hasil uji statistik spearman's rho diperoleh hasil $p$ value 0.624 yang berarti lebih besar dari 0.05, sehingga dapat disimpulkan bahwa $p$ value $>\alpha(0.624>0.05)$ maka $\mathrm{H}_{1}$ ditolak. berarti bahwa tidak ada hubungan tingkat pengetahuan dengan motivasi.

Kesimpulan: Tidak ada hubungan tingkat pengetahuan tentang HIV/AIDS dengan motivasi tes HIV. Diharapkan penelitian selanjutnya dapat mengembangkan penelitian yang terkait dengan HIV/AIDS pada wanita pekerja seks.
\end{abstract}

Kata Kunci :Pengetahuan, Motivasi, HIV, VCT 


\section{Abstract}

Backgroud: Human Immunodeficiency Virus (HIV) is a type of virus that attacks the immune system. Acquired Immunedeficiency Syndrome (AIDS) is a collection of symptoms of immune system damage. Voluntary Counseling Testing (VCT) is a program that aims to perform HIV screening with some requirements. With the increasing knowledge of WPS on HIV/AIDS, WPS can know, prepare, believe and so forth motivate the intention to act and finally there is a manifestation of intent in the conduct of HIV testing. This study aims to determine "Is there a correlation between the level of knowledge about HIV/AIDS with the motivation of HIV testing in female sex workers (WPS) in Bukit Sungkai Localization Km. 12 Palangka Raya".

Method:This research uses correlation research with cross-sectional approach that is the type of research that presses the measurement time or observation data of independent and dependent variable only once at one time (point time approach). Data collection using questionnaire.

Result:Based on statistical test result of spearman's rho obtained result $p$ value 0.624 which means bigger than 0.05, so it can be concluded that $p$ value $>\alpha(0.624>0.05)$ then H1 rejected. Means that there is no relationship of knowledge level with motivation.

Conclusion:It can be concluded that there is no relationship of knowledge level about HIV/AIDS with motivation of HIV test. It is hoped that further research can develop HIV/AIDS-related research in female sex workers.

Keywords: Level of Knowledge, Motivation, HIV, VCT

\section{PENDAHULUAN}

Human Immunodeficiency Virus (HIV) adalah jenis virus yang tergolong familia retrovirus, sel-sel darah putih yang diserang oleh HIV pada penderita yang terinfeksi adalah sel-sel limfosit T (CD4) yang berfungsi dalam sistem imun (kekebalan) tubuh. HIV memperbanyak diri dalam sel limfosit yang diinfeksinya dan merusak sel-sel tersebut, sehingga mengakibatkan sistem imun terganggu dan daya tahan tubuh berangsur-angsur menurun. Sedangkan Acquired Immune Deficiency Syndrome (AIDS) adalah suatu kumpulan gejala penyakit kerusakan sistem kekebalan tubuh, bukan penyakit bawaan tetapi dibuat dari hasil penularan. Penyakit ini disebabkan oleh Human Immunodeficiency Virus (HIV).
Penyakit ini telah menjadi masalah Internasional karena dalam waktu yang relatif singkat terjadi peningkatan jumlah pasien dan semakin melanda banyak Negara. Saat ini belum ditemukan vaksin atau obat yang efektif untuk pencegahan HIV/AIDS sehingga menimbulkan keresahan di dunia (Khaty F, 2015). Sebagai kelompok resiko tinggi Wanita Pekerja Seks (WPS) harus melakukan Voluntary Counselling \& Testing (VCT) secara rutin untuk menghindari terjadinya penularan HIV. Pengetahuan WPS mengenai HIV/AIDS masih cukup rendah, namun sebagian besar sudah melakukan tes HIV/AIDS secara rutin. WPS mempunyai motivasi intrinsik yang dapat menggerakkan, mengarahkan dan menopang tingkah laku 
Dinamika Kesehatan Jurnal Kebidanan dan Keperawatan Vol 11 No. 1 Juli 2020 ( ISSN: 2086-3454 EISSN: 2549-4058) url: http://ojs.dinamikakesehatan.unism.ac.id DOI : https://doi.org/10.33859/dksm.v11il

Hubungan Tingkat Pengetahuan Tentang Hiv/Aids Dengan Motivasi Tes Hiv Pada Wanita Pekerja Seks (WPS) Di Lokalisasi Bukit Sungkai Km 12 Palangka Raya

mereka dalam melakukan tes HIV/AIDS. Motivasi intrinsik untuk menggerakkan dan mengarahkan WPS berkaitan dengan keinginan dan harapan mereka yaitu ingin mengetahui status HIV nya dan untuk menjaga kesehatan (Andin V, 2013). Fenomena yang terjadi pada WPS di Lokalisasi Bukit Sungkai Km. 12 Palangkaraya menunjukan bahwa pengetahuan WPS cukup tinggi, namun keinginan motivasi untuk melakukan tes HIV sangatlah lemah.

HIV/AIDS sebagai salah satu epidemik yang paling menghancurkan pada sejarah, United National HIV/AIDS (UNAIDS) \& Word Health Organization (WHO) 2012 menyebutkan bahwa saat ini di dunia terjadi peningkatan jumlah orang dengan HIV/AIDS tahun 2010 sebanyak 2.7 juta orang hidup dengan HIV, dan di tahun 2012 secara global epidemik AIDS mencatat sebanyak 35.3 juta orang di dunia hidup dengan HIV. Sebanyak 2.3 juta orang di dunia baru terinfeksi virus HIV, dan kematian akibat AIDS diperkirakan sebanyak 1.6 juta orang diseluruh dunia. Sedangkan di Asia/Kepulauan Pasifik pada tahun 2012 diperkirakan 3.9 juta orang hidup dengan HIV, sebanyak 270.000 ribu orang yang baru terinfeksi virus HIV. Menurut hasil penelitian (Siti R.J, Ferry A, Heni W 2014) dengan judul Hubungan Pengetahuan Wanita Pekerja Seks (WPS) Voluntary Counseling Testing (VCT) Terhadap Perilaku Voluntary Counselling Testing (VCT) di Klinik Griya
Asa PKBI Kota Semarang. WPS dengan pengetahuan kurang sebagian besar melakukan VCT sebanyak 21 orang $(61,8 \%)$ dan sebagian kecil tidak melakukan VTC sebanyak 13 orang $(38,2 \%)$. Selanjutnya dari 22 WPS dengan pengetahuan baik sebagian besar melakukan VCT sebanyak 20 orang $(90,9 \%)$ dan sebagian kecil tidak melakukan VCT sebanyak 2 orang $(9,1 \%)$. Hasil uji statistic dengan menggunakan uji Chi Square dengan nilai 0.05 , diperoleh nilai $\mathrm{p}$-value 0,036 , perolehan tersebut lebih kecil dari 0,05 yang berarti bahwa ada hubungan antara tingkat pengetahuan WPS tentang VCT dengan perilaku VCT di Klinik Griya ASA PKBI Kalibanteng Kulon Semarang. Berdasarkan data yang diperoleh oleh peneliti di Dinas Kesehatan Kota Palangkaraya, jumlah kasus HIV positif yang dilaporkan pada tahun 2015 sebanyak 167 kasus ada peningkatan jumlah kasus bila dibandingkan dengan jumlah kasus tahun 2014 yang berjumlah 121. Sedangkan penderita AIDS pada tahun 2015 berjumlah 47 orang jauh lebih banyak bila dibandingkan dengan jumlah kasus pada pada tahun 2014 yang hanya berjumlah 15 orang di Kalimantan Tengah (Profil Kesehatan Kalteng, 2015). Dari survei pendahuluan yang dilakukan oleh peneliti pada tanggal 13 Maret 2017 terhadap 10 responden (100\%) bahwa lima responden (50\%) tidak tahu sama sekali saat ditanya apa itu HIV, penyebabnya, tanda gejala, penularan dan pencegahannya bahkan ada yang baru 
Dinamika Kesehatan Jurnal Kebidanan dan Keperawatan Vol 11 No. 1 Juli 2020 ( ISSN: 2086-3454 EISSN: 2549-4058)

url: http://ojs.dinamikakesehatan.unism.ac.id DOI : https://doi.org/10.33859/dksm.v11i1

Hubungan Tingkat Pengetahuan Tentang Hiv/Aids Dengan Motivasi Tes Hiv Pada Wanita Pekerja Seks (WPS) Di Lokalisasi Bukit Sungkai Km 12 Palangka Raya

mendengar tentang infeksi menular seksual itu sendiri. Sedangkan lima responden (50\%) lagi hanya mengetahui pengertian, dan cara penularan HIV/AIDS yang kata mereka adalah penyakit yang disebabkan oleh berganti-ganti pasangan saat berhubungan seksual. Namun saat saya menanyakan ke-10 responden tersebut pernahkah tes HIV, 8 responden menjawab tidak pernah karena takut kalau mengetahui hasil tes positif tertular HIV dan menurut mereka tes HIV itu tidak penting karena mereka kurang peduli akan kesehatan mereka.

Pengetahuan tentang penyakit HIV/AIDS bukanlah pengetahuan yang bersifat umum dan dasar. Pengetahuan tentang penyakit HIV/AIDS bagi WPS penting karena WPS merupakan kelompok yang berisiko tinggi terkena HIV/AIDS. Dengan pengetahuan WPS yang meningkat tentang HIV/AIDS, WPS dapat mengetahui, mempersiapkan, meyakini dan sebagainya sehingga menimbulkan motivasi niat untuk bertindak dan akhirnya terjadilah perwujudan niat yang berupa perilaku (Notoatmodjo, 2012). Teori Informasi, Motivasi dan Behaviour (IMB) dari Fisher \& Fisher berpendapat bahwa informasi, motivasi, dan keterampilan berperilaku merupakan factor utama yang dapat mempengaruhi perilaku pencegahan seseorang terhadap penyakit termasuk penyakit HIV/AIDS. Salah satu cara untuk mengurangi risiko penularan penyakit HIV/AIDS yaitu dengan te HIV pada WPS. Penatalaksanaan tes HIV yang efektif akan menurunkan prevalensi dan mencegah timbulnya komplikasi dan kelainan lebih lanjut yang menetap, mengurangi penyebaran penyakit dimasyarakat, dan memberikan peluang khusus dalam menjangkau kelompok sasaran dengan melakukan penyuluhan tentang upaya pencegahan infeksi HIV (Linda, J. 2006). WPS sering mendapatkan informasi mengenai kesehatan reproduksi khususnya tentang penyakit HIV/AIDS baik berupa penyuluhan, selebaran/leaflet, maupun dari media massa. Pengetahuan merupakan teknik, teori, dan fakta. Jadi pengetahuan dapat pula diwujudkan dalam tingkah laku. Pengetahuan yang dipunyai seseorang akan mempengaruhi seseorang dalam kegiatan sehari - hari antara lain perilaku dalam bidang kesehatan. Motivasi adalah suatu usaha yang di sadari untuk mempengaruhi tingkah laku WPS agar mereka bergerak untuk bertindak melakukan sesuatu sehingga mencapai hasil atau tujuan tertentu. Motivasi yang dimaksud adalah motivasi untuk melakukan tes HIV alasan mengapa WPS tidak mau melakukan tes HIV adalah karena takut mengetahui kalau positif tertular HIV juga kurangnya dorongan motivasi dari berbagai pihak seperti tenaga medis atau perawat, orang - orang sekitar, dan antar sesama WPS. Semakin rendah motivasi semakin sulit mengaplikasikannya dalam tingkah laku, dan sebaliknya semakin tinggi 
Dinamika Kesehatan Jurnal Kebidanan dan Keperawatan Vol 11 No. 1 Juli 2020 ( ISSN: 2086-3454 EISSN: 2549-4058) url: http://ojs.dinamikakesehatan.unism.ac.id DOI : https://doi.org/10.33859/dksm.v11i1

Hubungan Tingkat Pengetahuan Tentang Hiv/Aids Dengan Motivasi Tes Hiv Pada Wanita Pekerja Seks (WPS) Di Lokalisasi Bukit Sungkai Km 12 Palangka Raya

motivasi semakin baik pula dalam mengaplikasikannya kedalam tingkah laku.

Tingginya angka kejadian HIV/AIDS di kalangan WPS, terutama WPS merupakan bukti bahwa masih rendahnya pengetahuan akan HIV dan motivasi tes HIV. WPS dalam hal ini yang sering mlakukan hubungan seks berisiko tertularnya HIV dan bisa menularkan ke orang lain sehingga perlu adanya promosi kesehatan baik dalam bentuk pendidikan kesehatan langsung tentang HIV, agar mereka tidak cukup hanya dengan tahu tetapi diharapkan setelah mereka mengetahuinya mereka mau menerapkannya dan mampu melakukan tes HIV. Peran perawat dapat memberikan konseling pre dan pasca tes HIV dan

motivasi untuk mendorong orang

melakukan tes HIV. Pada konseling dibahas mengenai risiko penularan HIV, cara tes, interpretasi tes, perjalanan penyakit HIV serta dukungan yang dapat diperoleh penderita. Konsekuensi dari hasil tes postif maupun negatif disampaikan dalam sesi konseling. Dengan demikian orang yang akan menjalani testing telah dipersiapkan untuk menerima hasil apakah hasil tersebut positif atau negatif.

\section{METODE}

Penelitian ini menggunakan penelitian korelasi dengan pendekatan cross- sectional yaitu jenis penelitian yang menekan waktu pengukuran atau observasi data variable independen dan dependen hanya satu kali pada satu saat (point time approach). Tentunya tidak semua subjek penelitian harus di observasi pada hari atau pada waktu yang sama akan tetapi variable independen maupun variable dependen dinilai hanya satu kali saja (Nursalam, 2013).

\section{HASIL}

Analisa hubungan tingkat pengetahuan tentang HIV/AIDS dengan motivasi tes HIV pada Wanita Pekerja Seks (WPS) di Lokalisasi Bukit Sangkai Km. 12 Palangka Raya. (Agustus 2017)

Tabel 1 Uji Statistik pengetahuan dan motivasi pada wanita pekerja seks di Lokalisasi Bukit Sangkai Km. 12 Palangka Raya. (Agustus 2017)

\begin{tabular}{|c|c|c|c|c|}
\hline & & & $\begin{array}{c}\text { Tingkat } \\
\text { Pengeta } \\
\text { huan }\end{array}$ & $\begin{array}{c}\text { Motiv } \\
\text { asi }\end{array}$ \\
\hline \multirow{6}{*}{$\begin{array}{c}\text { Spear } \\
\text { man's } \\
\text { Rho }\end{array}$} & \multirow{3}{*}{$\begin{array}{l}\text { Tingkat } \\
\text { pengeta } \\
\text { huan }\end{array}$} & $\begin{array}{l}\text { Correlation } \\
\text { Coefficient }\end{array}$ & 1.000 & -.093 \\
\hline & & $\begin{array}{l}\text { Sig.(2- } \\
\text { tailed) }\end{array}$ & . & .624 \\
\hline & & $N$ & 30 & 30 \\
\hline & \multirow[t]{3}{*}{ Sikap } & $\begin{array}{l}\text { Correlation } \\
\text { Coefficient }\end{array}$ & -.093 & 1.000 \\
\hline & & $\begin{array}{l}\text { Sig. }(2- \\
\text { tailed })\end{array}$ & .624 & . \\
\hline & & $N$ & 30 & 30 \\
\hline
\end{tabular}

Berdasarkan hasil uji statistik spearman's rho hubungan tingkat pengetahuan tentang HIV/AIDS dengan motivasi tes HIV pada Wanita Pekerja Seks (WPS) di Lokalisasi Bukit Sangkai Km. 12 Palangka Raya, di dapatkan nilai berdasarkan signifikansi diperoleh $p$ value 0.624 yang 
Dinamika Kesehatan Jurnal Kebidanan dan Keperawatan Vol 11 No. 1 Juli 2020 ( ISSN: 2086-3454 EISSN: 2549-4058) url: http://ojs.dinamikakesehatan.unism.ac.id DOI : https://doi.org/10.33859/dksm.v11il

Hubungan Tingkat Pengetahuan Tentang Hiv/Aids Dengan Motivasi Tes Hiv Pada Wanita Pekerja Seks (WPS) Di Lokalisasi Bukit Sungkai Km 12 Palangka Raya

berarti lebih besar dari 0.05 , sehingga dapat disimpulkan bahwa $p$ value $>\alpha(0.624>0.05)$ maka $\mathrm{H}_{1}$ ditolak. Artinya tidak ada hubungan tingkat pengetahuan tentang HIV/AIDS dengan motivasi tes HIV pada Wanita Pekerja Seks (WPS) di Lokalisasi Bukit Sangkai Km. 12 Palangka Raya.

\section{PEMBAHASAN}

Berdasarkan hasil analisa uji statistik hubungan tingkat pengetahuan tentang HIV/AIDS dengan motivasi tes HIV pada Wanita Pekerja Seks (WPS) di Lokalisasi Bukit Sangkai Km. 12 Palangka Raya, di dapatkan nilai berdasarkan signifikansi diperoleh $p$ value 0.624 yang berarti lebih besar dari 0.05 , sehingga dapat disimpulkan bahwa $p$ value $>\alpha(0.624>0.05)$ maka $\mathrm{H}_{1}$ ditolak. Artinya tidak ada hubungan tingkat pengetahuan tentang HIV/AIDS dengan motivasi tes HIV pada Wanita Pekerja Seks (WPS) di Lokalisasi Bukit Sangkai Km. 12 Palangka Raya.

Berdasarkan teori pengetahuan adalah merupakan hasil dari "tahu" dan ini terjadi setelah orang melakukan penginderaan terhadap suatu objek tertentu. Penginderaan terhadap objek terjadi melalui panca indera manusia, yakni penglihatan, pendengaran, penciuman, rasa, dan raba dengan sendiri pada waktu penginderaan sampai menghasilkan pengetahuan tersebut sangat dipengaruhi oleh intensitas perhatian persepsi terhadap obyek. Sebagian besar pengetahuan manusia di peroleh melalui mata dan telinga (Notoatmodjo 2012;138). Faktor yang mempengaruhi tingkat pengetahuan seseorang, terdiri dari pendidikan, sosial budaya, dan ekonomi, status ekonomi, lingkungan, pengalaman, usia. Lingkungan adalah segala sesuatu yang ada disekitar individu, baik lingkungan fisik, biologis, maupun sosial. Lingkungan berpengaruh terhadap proses masuknya pengetahuan kedalam individu yang berada dalam lingkungan tersebut. Hal ini terjadi karena adanya interaksi timbal balik ataupun tidak, yang akan di respon sebagai pengetahuan oleh setiap individu. (Budiman, 2014; 4).

Berdasarkan hasil penelitian yang didapatkan menunjukan bahwa terdapat kesamaan antara fakta dan teori didapatkan bahwa responden dominan memiliki tingkat pengetahuan yang kurang dan sebagian belum pernah mendapatkan informasi mengenai pentingnya tes HIV. Hal tersebut menurut peneliti dapat disebabkan karena ada beberapa faktor yang dapat mempengaruhi tingkat pengetahuan responden yaitu lingkungan informasi, pengalaman, dan sosial, yang pada penelitian ini dominan responden memiliki tingkat pengetahuan kurang. Hal ini dikarenakan responden kurang mendapatkan informasi mengenai HIV/AIDS itu dari petugas kesehatan. Petugas kesehatan ini berpengaruh terhadap proses masuknya 
Dinamika Kesehatan Jurnal Kebidanan dan Keperawatan Vol 11 No. 1 Juli 2020 ( ISSN: 2086-3454 EISSN: 2549-4058) url: http://ojs.dinamikakesehatan.unism.ac.id DOI : https://doi.org/10.33859/dksm.v11il

Hubungan Tingkat Pengetahuan Tentang Hiv/Aids Dengan Motivasi Tes Hiv Pada Wanita Pekerja Seks (WPS) Di Lokalisasi Bukit Sungkai Km 12 Palangka Raya

pengetahuan tentang HIV/AIDS dalam kehidupan sehari-hari. Dimana disini responden hanya mendapatkan informasi dari media massa dan keluarga atau teman saja, sedangkan informasi tentang HIV/AIDS dari petugas kesehatan maupun keluarga atau teman itu kurang. Dalam pengalaman, responden ada yang tidak pernah dan hanya sedikit yang mendapatkan pendidikan kesehatan tentang HIV/AIDS. Padahal HIV/AIDS ini sangat penting bagi kehidupan wanita pekerja seks untuk meningkatkan status kesehatan mereka. Jadi, pada penelitian ini didapatkan tingkat pengetahuan responden kurang.

Berdasarkan hasil penelitian menunjukan ada kesenjangan antara fakta dan teori, didapatkan bahwa tidak ada hubungan tingkat pengetahuan tentang HIV/AIDS dengan motivasi tes HIV pada Wanita Pekerja Seks (WPS) di Lokalisasi Bukit Sungkai Km. 12 Palangka Raya. Jadi, pada penelitian ini didapatkan tingkat pengetahuan responden kurang. Berdasarkan pendidikan terakhir responden wanita pekerja seks (WPS) didapatkan bahwa responden lebih dominan hanya sampai dengan tingkat Sekolah Menengah Pertama (SMP), sehingga tingkat pengetahuan responden menjadi kurang. Tingkat pengetahuan yang kurang belum tentu berhubungan dengan motivasi yang lemah. Hal ini dapat dikarenakan seseorang memiliki motivasi yang berbeda - beda, hal ini tidak dapat mempengaruhi tingkat pengetahuan seseorang yang baik, cukup, maupun kurang belum tentu membuat motivasi seseorang tersebut menjadi kuat, sedang, maupun lemah. Motivasi seseorang yang lemah tidak mutlak ditentukan oleh tingkat pengetahuan seseorang melainkan dapat ditentukan dari berbagai faktor tertentu seperti lingkungan sekitar yang dapat membuat motivasi atau pemikiran berubah - ubah tergantung dari tempat tinggal dimana lingkungan tersebut mempunyai orang - orang yang memiliki pemikiran dan tingkah laku yang negatif sehingga orang yang bergaul atau berteman dengan pemikiran atau tingkah laku seseorang di lingkungan tersebut dapat mengubah pemikiran atau tingkah laku seseorang yang baik menjadi negatif karena penyesuaian diri seseorang pendatang dari suatu lingkungan yang sudah terdokstrin pemikiran yang negatif sehingga membuat responden terpengaruh pada pemikiran yang negatif tentang tes HIV, dimana hal tersebut dapat mempengaruhi responden memiliki pemikiran yang negatif terlebih dahulu mengenai tes HIV, sehingga dapat membuat responden tidak termotivasi untuk melakukan tes HIV.

\section{KESIMPULAN}

Hubungan tingkat pengetahuan tentang HIV/AIDS dengan motivasi tes HIV pada Wanita Pekerja Seks (WPS) di Lokalisasi Bukit Sangkai Km. 12 Palangka Raya, 
Dinamika Kesehatan Jurnal Kebidanan dan Keperawatan Vol 11 No. 1 Juli 2020 ( ISSN: 2086-3454 EISSN: 2549-4058) url: http://ojs.dinamikakesehatan.unism.ac.id DOI : https://doi.org/10.33859/dksm.v11il

Hubungan Tingkat Pengetahuan Tentang Hiv/Aids Dengan Motivasi Tes Hiv Pada Wanita Pekerja Seks (WPS) Di Lokalisasi Bukit Sungkai Km 12 Palangka Raya

menunjukkan $\mathrm{N}$ sebanyak 30 sampel, nilai berdasarkan signifikansi diperoleh $p$ value 0.624 yang berarti lebih besar dari 0.05, sehingga dapat disimpulkan bahwa $p$ value $>\alpha$ (0.624 > 0.05) maka H1 ditolak. Artinya tidak ada hubungan tingkat pengetahuan tentang HIV/AIDS dengan motivasi tes HIV pada Wanita Pekerja Seks (WPS) di Lokalisasi Bukit Sangkai Km. 12 Palangka Raya.

\section{SARAN}

Dapat menjadi acuan serta sebagai landasan dan gambaran untuk penelitian selanjutnya tentang hubungan tingkat pengetahuan tentang HIV/AIDS dengan motivasi tes HIV pada Wanita Pekerja Seks (WPS).

\section{DAFTAR PUSTAKA}

Agus riyanto, Budiman. 2013. Kapita Selekta Kueisoner : Pengetahuan Dan Perilaku Dalam Pemelitian Kesehatan. Jakarta : Salemba Medika

Agus, Rahmadi. 2002. "Teology Pembebasan Untuk PSK" http://groups.google.co.id/group/soc.c ulture.indonesia Diakses pada tanggal 4 April 2017

A.A. Anwar Prabu Mangkunegara. 2001, Manajemen sumber daya manusia perusahaan, Bandung : Remaja Rosdakarya

Ardarini, Mailila. 2006. "62 Tahun Merdeka, Anak Indonesia Masih Dilema "http://www.ri.go.id/id/index.php? Diakses pada tanggal 4 April 2017
Andrews, Gilly. 2009. Buku Ajar Kesehatan Reproduksi Wanita. Ed 2. Jakarta: EGC.

Arikunto, S. 2010. Prosedur Penelitian Suatu Pendekatan Praktik. Jakarta: PT Rineka Cipta

Andin, V. (2013). Motivasi Wanita Pekerja Seks (WPS) Dalam Melakukan Tes HIV/AIDS. Diunduh pada tanggal 3 April 2017.

Arep, I dan Tanjung, H. (2003). Manajemen Motivasi. Jakarta: Grasindo.

Budiman. 2014. Ilmu Dasar Pengetahuan dan Sikap dalam Penelitian Kesehatan. Jakarta: Salemba Medika

Chandraa, Budiman. 2009. Metodologi Penelitian Kesehatan. Jakarta: EGC

Djuanda, Adhi. 2010. Ilmu Penyakit Kulit Dan Kelamin. Ed. 5. Jakarta: Fekultas Kedokteran Universitas Indonesia.

Dahlan Sopiyudin. 2010. Membuat Proposal Penelitian Bidang Kedokteran dan Kesehatan. Jakarta: EGC

DepKes RI, 2004. Sistem Kesehatan Nasional 2004, Jakarta. Diakses 27 Februari 2017 dari http.depkes.go.id

Dinkes. 2015. Profil Kesehatan Kalimantan Tengah. Diakses 27 Februari 2017 dari http.dinkeskalimantantengah.go.id

Fitriani, Sinta. 2011. Promosi Kesehatan. Yogyakarta: Graha Ilmu.

Glasier, Anna, Alisa Gebbie. 2005. Keluarga Berencana dan Kesehatan Reproduksi. Jakarta: EGC.

Gunarsa \& Gunarsa. (2000). Psikologi Praktis : Anak Remaja dan Keluarga. Jakarta : PT. BPK Gunung Mulia. 
Dinamika Kesehatan Jurnal Kebidanan dan Keperawatan Vol 11 No. 1 Juli 2020 ( ISSN: 2086-3454 EISSN: 2549-4058) url: http://ojs.dinamikakesehatan.unism.ac.id DOI : https://doi.org/10.33859/dksm.v11i1

Hubungan Tingkat Pengetahuan Tentang Hiv/Aids Dengan Motivasi Tes Hiv Pada Wanita Pekerja Seks (WPS) Di Lokalisasi Bukit Sungkai Km 12 Palangka Raya

Hasibuan, Malayu S.P. (2009). Organisasi dan Motivasi:Dasar Pemikiran Produktifitas. Cetakan ke-2. Jakarta: Bumi Aksara.

Heffer,Linda J, Danny J Schust. 2006. Sistem Reproduksi. Ed.2. Jakarta: Erlangga.

Hidayat, A. 2007. Riset Keperawatan dan Tehnik Penulisan Ilmiah. Jakarta: Salemba Medika

Hidayat,A.A. 2011. Metode Penelitian Keperawatan dan Teknik Analisi Data, Jakarta :Salemba Medika

Hukumonline. 2007. "Menyoroti Sisi Gelap Child Trafficking diIndramayu" http://Hukumonline.com/detail.asp?id $=10805 \&$ et $=$ fokus Diakses pada tanggal 4 April 2017

IBI. 2006. 50 Tahun IBI Bidan menyongsong Masa depan, IBI, Jakarta.

IBI. (2002). Teori Motivasi dan Aplikasinya, Jakarta: Bumi Aksara.

Khaty, F. 2015. Kesehatan Seksual. Jakarta: Bumi Medika

Kalicchman, S. C. 1998. Preventing AIDS, A Sourcebook for Behavioral Interventions. London: LEA Press

Kasnodihardjo. 2001. "Dinamika Pelacuran di wilayah Jakarta dan Surabaya dan Faktor Sosio Demografi yang melatar belakanginya", Depkes RI, Jakarta. http://www.kalbe.co.id/fiks/dinamikap elacuran.pdf/ Diakses pada tanggal 4 April 2017

Komisi Penanggulangan AIDS Yogyakarta. 2014. Kasus HIV/AIDS di Kulonprogo. Diakses tanggal 4 April 2017.Http://krjogja.com/read/195609/ pantau-penyebaran-hivaids-dinkessiapkan-dpa.kr.
Manuaba, Ida Ayu Chandranita. 2009. Memahami Kesehatan Reproduksi Wanita. Ed. 2. Jakarta: EGC

Mahardika, Asmar. 2004. Tuhan Singgah Di Pelacuran, Kreasi Wacana, Yogyakarta.

Makhfudi, Efendy Ferry. 2009. Keperawatan Kesehatan Komunitas, Teori Dan Preaktik Dalam Keperawatan. Jakarta : Salemba Medika

Murtiastutik, Dwi, dkk. 2011. Atlas Penyakit Kulit dan Kelamin. Ed.2. Surabaya: Pusat Penerbitan dan Percetakan.

Mudjijono. (2005).Sarkem, Reproduksi Sosial Pelacuran.Yogyakarta : Gajah Mada University Press.

Nasution, Z. 1990. Prinsip-Prinsip Komunikasi Untuk Penyuluhan. Lembaga Penerbit Fakultas Ekonomi Universitas Indonesia. Jakarta.

Nugraha, Boyke Dian. 2013. It's All About Sex: a-z. Tentang Seks. Jakarta: Bumi Aksara.

Notoatmojo. 2010. Metodologi Penelitian Kesehatan. Jakarta: Rineka Cipta

Notoatmojo. 2012. Promosi Kesehatan dan Perilaku Kesehatan. Jakarta: Rineka Cipta

Nursalam. 2009. Konsep dan Penetapan Metodologi Penelitian Ilmu Keperawatan, Edisi 2 Pedoman Skripsi, Tesis, dan Instrumen Penelitian Keperawatan. Jakarta: Salemba Medika

Nursalam. 2011. Konsep dan Penerapan Metodelogi Penelitian Ilmu Keperawatan. Jakarta : Salemba Medika 
Dinamika Kesehatan Jurnal Kebidanan dan Keperawatan Vol 11 No. 1 Juli 2020 ( ISSN: 2086-3454 EISSN: 2549-4058) url: http://ojs.dinamikakesehatan.unism.ac.id DOI : https://doi.org/10.33859/dksm.v11il

Hubungan Tingkat Pengetahuan Tentang Hiv/Aids Dengan Motivasi Tes Hiv Pada Wanita Pekerja Seks (WPS) Di Lokalisasi Bukit Sungkai Km 12 Palangka Raya

Nursalam. (2014). Manajemen Keperawatan: Aplikasi Dalam Praktik Keperawatan Profesional. Jakarta: Salemba Medika

Satiadarma, P. 2001. Persepsi Orang Tua Membentuk Prilaku Anak, Pustaka Populer Obor, Jakarta.

Sardiman, A.M. (2001). Interkasi dan Motivasi Belajar-Mengajar. Cet. IX, Jakarta: Raja grafindo Persada.

Subadara, I Nengah. 2007. "Bali Tourism Watch : Keberadaan Pekerja Seks Komersial sebagai dampak negative Pariwisata di Bali'http://www.subadara.wordpress.c om. Diakses pada tanggal 3 April 2017

Trisnadi. 2004. Dolly Hitam Putih Prostitusi, Gagas Media, Jakarta.

UNAIDS, (2011). Men Sex Men (MSM) Report World Bank (2011). Diakses pada tanggal $07 \quad$ April 2017. www.who.int/MSM/data/en

Yustinawaty. 2007. "Perempuan \& Kemiskinan"

http://www.seputarindonesia.com/edis icetak/05/07

Wahid, Abdul. 2001. Perlindungan Terhadap Kekerasan Seksual, Refika Aditama, Bandung.

Wahjosumidjo. (2004). Kepemimpinan dan Motivasi, Jakarta:Ghalia Indonesia.

Winardi, J. (2007). Motivasi dan Pemotivasian dalam Manajemen, Jakarta: Raja Grafindo Persada

World Health Organization. 2012. HIV/AIDS Data and Statistics. Diakses pada tanggal $07 \quad$ April 2017. www.who.int/hiv/data/en.

WIKIPEDIA, 2007. "PELACURAN"
http://id.wikipedia.org/wiki/pelacuran
\#pelacur
\#pelacur 